\section{Demographic and Clinical Profile of Oral Squamous Cell Carcinoma from a Service-Based Population}

\author{
Alessandro Menna Alves ${ }^{1,2,3}$, Marcos Britto Correa ${ }^{1}$, Karine Duarte da Silva ${ }^{1,2}$, \\ Lenita Maria Aver de Araújo ${ }^{2}$, Ana Carolina Uchoa Vasconcelos ${ }^{1,2}$, Ana Paula \\ Neutzling Gomes ${ }^{1,2}$, Adriana Etges ${ }^{1,2}$, Sandra Beatriz Chaves Tarquinio ${ }^{1,2}$
}

'Graduate Program in Dentistry, UFPel - Universidade Federal de Pelotas, Pelotas, RS, Brazil ${ }^{2}$ Center of Diagnosis of Oral Diseases, UFPel - Universidade Federal de Pelotas, Pelotas, RS, Brazil ${ }^{3}$ Dental School, UNIVATES - Unidade Integrada Vale do Taquari de Ensino Superior, Lajeado, RS, Brazil

Correspondence: Sandra Beatriz Chaves Tarquinio, Rua Gonçalves Chaves 457, s/607, 96015-560, Pelotas, RS, Brasil. Tel: +55-53-981112894. e-mail: sbtarquinio@gmail.com

Key Words: mouth neoplasms, epidemiology, population groups, oral health.

\section{Introduction}

Generally, oral cancer represents around 5\% of all human malignancies (1), as observed by the wide geographical variation in its incidence (2). In some parts of the globe it is the most frequent type of cancer, such as in south Asia, including India and some islands in Melanesia, mainly due to smoking and chewing tobacco habits $(2,3)$. In other areas oral cancer shows great incidence, such as Sri Lanka, Pakistan and Taiwan; and also in some European countries, and in Latin American countries such as Brazil, Uruguay, Puerto Rico and Cuba (3). In Brazil, oral cancer represents the sixth neoplasm, since the OSCC is the most prevalent one (94\% of all oral tumors), which occurs mainly in individuals over 45 years old. Although several studies about OSCC have been performed, more than 50\% of the patients died within 5 years after the diagnosis. The prognosis for OSCC is variable due to the multiple variables implicated in its development, such as extension and location of the primary tumor, degree of invasion of neighboring structures, presence of regional and distant metastasis, histological types, the chosen therapy and the general health status of the patient (3).

The etiologic factors strongly associated with the development of OSCC are the consumption of tobacco and alcohol $(3,4)$. However, in recent decades, there has been an increasing trend of OSCC development in females and young adults, for whom other etiological factors like genetic heritage, dietary habits and Human Papilomavirus (HPV) infection have been pointed out as causes (5-7). It has been observed that environmental and cultural differences may be closely related to the average occurrence of OSCC. Therefore, the knowledge of demographic and clinical profile of OSCC in different populations is important and relevant. In this way, many other studies have approached it, with emphasis on Brazilian surveys (8-10) and revealed status of important considerations about this disease in specific populations.

In southern Brazil, the Center of Diagnosis of Oral Diseases (CDOD) is considered a reference service for clinical and histopathological diagnosis of oral diseases. CDOD attended approximately 20,000 biopsy samples from 1959 to present, amounting to around 1.500 patients per year. In mind with the importance of the impact of oral cancer campaigns in the prevention and early diagnosis of this disease $(11,12)$, this oral diagnosis service has promoted campaigns of prevention and detection of oral cancer in the last 15 years. Until the present moment, no other epidemiological study about OSCC was carried out at this center and knowing the demographic and clinical 
profile of the patients attended in this service can help the establishment of strategies for prevention and early detection of OSCC.

The aim of this study was to evaluate the demographic and clinical profile of OSCC cases registered at a center of clinical and histopathological diagnosis, located in southern Brazil.

\section{Material and Methods}

All cases of OSCC were retrieved from the CDOD files of, the Dental School, Universidade of the Federal de Pelotas, RS, Brazil, from 1959 to 2012. They represent 806 individuals. This study was approved by the Ethics Committee, Universidade Federal de Pelotas (protocol number 058/2008).

\section{Demographic Data}

The data were categorized as followed: age of individual in decades (9); sex (male and female); skin color in white and non-white (referred by the professional) (10); the occupation according to the workplace, exposed or non-exposed to chronic solar radiation (10) (indoor or outdoor occupation).

\section{¿ Clinical and Histopathological Data}

Initially, were collected data about when the histopathological diagnosis of OSCC was done. Then, the habits of tobacco and alcohol consumption were registered as dichotomous variables, based on present or past consume of any quantity and frequency (8). The following clinical parameters collected from the files of CDOD were: tumor location (vermilion of lower and upper lip, labial mucosa, lateral border/ventral surface of the tongue, dorsum of the tongue, floor of the mouth, gingiva/alveolar ridge, buccal mucosa, palate and tonsils); tumor size (categorized as up to $2 \mathrm{~cm}, 2.1-4 \mathrm{~cm}$ and over $4 \mathrm{~cm}$ ) and the reported evolution time of the lesions (up to 6 months, 6.1-12 months and over 12 months). Additionally, were registered: pain (dichotomic variable), clinical appearance and lymph node involvement (dichotomic variable). All clinical variables were categorized similarly to Pires et al. (8) and Marocchio et al. (9).

The evaluated histopathological variants of OSCC were basaloid squamous carcinoma, verrucous carcinoma and spindle cell carcinoma.

\section{Statistical Analysis}

Data were double-typed using EPIDATA version 3.1 (EpiData Association, Odense, Denmark) and the consistency of information was subsequently verified. For data analysis, the software STATA version 11.0 (Stata Corporation, College Station, TX, USA) was used. Descriptive analyses were performed to describe and to calculate the frequency of interest variables of the study. The associations between variables were assessed using the chi-square and Fisher's tests, with a confidence level of $p<0.05$.

\section{Results}

From January 1959 to December 2012, a total of 20.206 samples were processed in CDOD, with 806 (3.9\%) cases being diagnosed as oral squamous cell carcinoma or its histological variants, with a high frequency in males $(76.6 \%$ [73.5; 79.4]) and white individuals (92.2\% [90.0; 94.0]) (Table 1). From all the OSCC, $186(23.1 \%)$ were diagnosed from 1959 to 1996 (total number of biopsies in the period=8148). The other 620 cases (76.9\%) were diagnosed from 1996 to 2012 (total number of biopsies=12 058). The mean age was 57.7 years (19-90), with the majority of cases distributed between 51 and 70 years old (53.9\%) (Fig. 1).

The most frequent sites were lower lip vermilion, followed by lateral border/ventral surface of the tongue, gingiva/alveolar ridge and floor of the mouth (Table 2). Ulcer was the most common clinical appearance (Table 2). The data about histological variants, reported evolution time, size of the lesions, pain, and lymph nodes are also indicated in Table 2.

There is a strong association between outdoor occupation, mainly farmers and LSCC $(p<0.001)$. While workers with outdoor occupation showed a $47.4 \%(n=129)$ frequency of OSCC. Individuals who worked in indoor occupations or were retired presented frequencies of 22.5\% $(n=53)$ and $23.5 \%(n=58)$, respectively. Skin color was also associated with this site. Lower lip vermilion lesions were also more commonly found in white individuals, 34.2\% $(n=226)$, in comparison with non-white, $1.8 \%(n=1)(p<0.001)$.

The association between size and lesions characteristics, Lymph node involvement and associations, and pain and associations are presented in Tables, 3, 4 and 5, respectively. The OSCC lesions located on the tongue were commonly greater than $2 \mathrm{~cm}$ (Table 3 ) and frequently presented lymph node involvement (Table 5). Similar positive and statistically significant associations were observed also for gingiva/ alveolar ridge and floor of the mouth (Tables 4 and 5). On the contrary, lesions located in the lower lip demonstrated the smallest size at the time of the diagnosis (Table 3 ) and rare lymph node involvement (Table 4).

The present study showed an association between pain and intraoral OSCC lesions, especially with those located in the most frequent sites as the tongue, floor of the mouth, and gingiva/alveolar ridge (Table 5) and between pain and the size of the lesions (Table 5). The greater the lesions, more painful they were (Table 5).

\section{Discussion}

The present study is a retrospective analysis of demographic and clinical profile of OSCC cases registered 
in an oral diagnosis center located in southern Brazil. This disorder is the most frequent type of oral cancer (2), what justifies the importance of epidemiological studies in this field. Regarding the frequency between sexs, OSSC was more frequent in males $(76.6 \%)$, corroborating the global literature for $\operatorname{OSCC}(3,16)$ that demonstrate a two-fold index of oral cancer among males compared to females $(5,16)$. The greater male indulgence of the main risk factors of OSCC such as tobacco and alcohol consumption for intraoral OSCC and sunlight exposure for LSCC could explain it (3). However, some studies have reported a decrease in the male-female ratio, attributing this change to different factors such as alteration of tobacco and alcohol habits, cultural and geographic peculiarities $(17,18)$.

Most diagnosed patients in this study were between 51 and 70 years old (53.9\%), which is in accordance with the literature $(3,9,16,19)$ indicating that age is probably a risk

Table 1. Descriptive analysis of individual variables (demographic and behavioral). Pelotas, Brazil ( $\mathrm{N}=806)$

\begin{tabular}{lcc}
\hline Variable & $\begin{array}{c}\text { Absolute } \\
\text { frequency }\left(\mathrm{n}^{0}\right)\end{array}$ & $\begin{array}{c}\text { Relative frequency } \\
{[\%(95 \% \mathrm{CI})]}\end{array}$ \\
\hline Sex & & \\
Female & 189 & $23.4(20.6 ; 26.5)$ \\
Male & 617 & $76.6(73.5 ; 79.4)$ \\
Skin color ${ }^{1}$ & & $92.2(90.0 ; 94.0)$ \\
White & 661 & $7.8(6.0 ; 10.0)$ \\
Non-white & 56 & $89.5(86.4 ; 92.1)$ \\
Smoking 2 & & $10.5(7.9 ; 13.6)$ \\
Yes & 427 & \\
No & 50 & $84.4(79.3 ; 88.7)$ \\
Alcoholism & & \\
Yes & & $15.6(11.3 ; 20.7)$ \\
No & 211 & $40.6(36.9 ; 44.4)$ \\
Occupation & & $35.2(31.6 ; 39.0)$ \\
Indoor & 39 & $24.2(21.0 ; 27.6)$ \\
Outdoor & & \\
Retired & 272 &
\end{tabular}

Data not informed: $89^{1}, 329^{2}, 556^{3}, 136^{4}$.

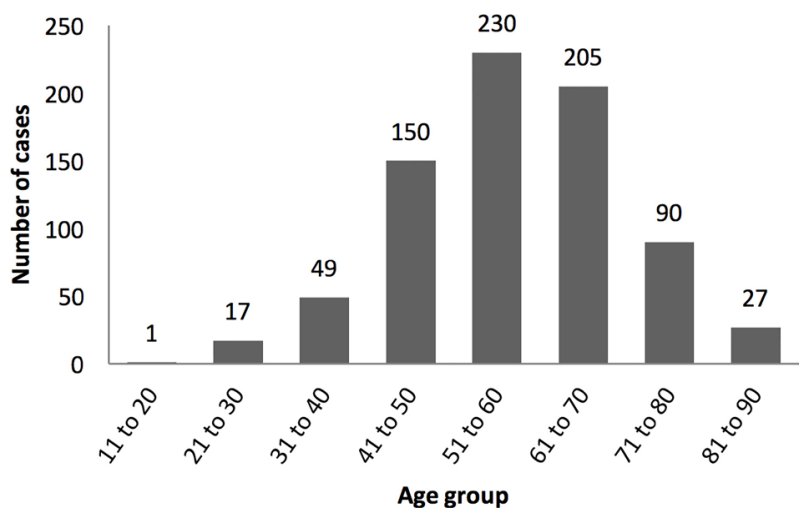

Figure 1. Distribution of cases according to age.
Table 2. Descriptive analysis of lesions characteristics (histological variant, referred time of evolution, clinical appearance, size, site, pain, and presence of lymph nodes). Pelotas, Brazil ( $\mathrm{N}=806)$.

\begin{tabular}{lcc}
\hline Variable & $\begin{array}{c}\text { Absolute } \\
\text { frequency } \\
\left(\mathrm{n}^{\circ}\right)\end{array}$ & $\begin{array}{c}\text { Relative } \\
\text { frequency } \\
{[\%(95 \% \mathrm{CI})]}\end{array}$ \\
\hline $\begin{array}{l}\text { Histological variant } \\
\text { Squamous cell carcinoma }\end{array}$ & 780 & $96.8(95.3 ; 97.9)$ \\
Verrucous carcinoma & 24 & $3.0(1.9 ; 4.4)$ \\
Basaloid squamous carcinoma & 1 & $0.1(0.0 ; 0.6)$ \\
Spindle cell carcinoma & 1 & $0.1(0.0 ; 0.6)$
\end{tabular}

Referred evolution time ${ }^{1}$

Up to 6 months

$55.8(52.3 ; 59.3)$

6-12 months

$21.6(18.8 ; 24.6)$

Over 12 months

Clinical appearance ${ }^{2}$

Ulcer

$69.9(66.6 ; 73.0)$

Leukoplakia

$12.7(10.4 ; 15.1)$

Erithroplakia

$2.2(1.3 ; 3.5)$

Leukoerithroplakia

Association

$1.9(1.0 ; 3.1)$

Size $^{3}$

Up to $2 \mathrm{~cm}$

$50.4(48.8 ; 55.9)$

$2.1-4 \mathrm{~cm}$

$33.3(31.5 ; 38.1)$

Over $4 \mathrm{~cm}$

Site

Lower lip vermilion

$23.3(20.4 ; 26.4)$

Upper lip vermilion

Labial mucosa

$1.7(0.9 ; 2.9)$

Lateral border/ventral surface of the tongue

Dorsum of the tongue

Buccal mucosa

Floor of the mouth

Gingiva/alveolar ridge

Palate

Tonsils

Pain ${ }^{4}$

Yes

No

Lymph node involvement ${ }^{5}$

Yes

No

110

$41.5(38.0 ; 44.9)$

Data not informed: $279^{1}, 168^{2}, 286^{3}, 375^{4}, 541^{5}$. 
marker for OSCC (16). However, Patel et al. (6) showed an increased incidence among white female young individuals, aged 18 to 44 years, postulating that there may be a new and emerging head and neck cancer population.

Concerning all the anatomical oral sites, lower lip vermilion represented the most frequent location (23.3\%), corroborating data from the literature $(10,16)$. The major frequency of OSCC lesions in this site has great relevance when the studies are performed in tropical countries, in addition to the important influence by socio-demographic (like ethnic origin), main occupation and cultural aspects of the studied population $(10,16,20)$.

It showed a strong association between outdoor occupation, mainly farmers and LSCC. Also between white skin color and this site, as previously demonstrated (10). Although the biopsy registers do not provide the occupation of the retired patients, it is possible that most of them live in rural areas, which would reinforce this correlation. Moreover, the lower lip is subjected to intense and chronic sun exposure and thus ultraviolet (UV) radiation, which may contribute to it being the most common site for OSCC in males and in populations of fair-skinned people $(16,20,21)$. For women, the use of lipstick could be $\vec{s}$ considered as a potential protective factor (17). In addition, factors like socio-demographic characteristics, lifestyle, immunosuppression and genetic susceptibility might

Table 3. Association between size and lesions characteristics

\begin{tabular}{lcccc}
\hline \multirow{2}{*}{ Variable/Category } & \multicolumn{5}{c}{ Size, n (\%) } \\
\cline { 2 - 5 } & $<2 \mathrm{~cm}$ & $2.1-4 \mathrm{~cm}$ & $>4 \mathrm{~cm}$ & $\mathrm{p}$ value \\
\hline Site & & & & \\
Lower lip vermilion & $140(51.5)$ & $27(16.9)$ & $5(5.7)$ & $<0.001$ \\
Upper lip vermilion & $4(1.5)$ & $0(0.0)$ & $1(1.1)$ & 0.313 \\
Labial mucosa & $4(1.5)$ & $2(1.3)$ & $2(2.3)$ & 0.815 \\
Lateral border/ventral & $51(18.8)$ & $54(33.8)$ & $28(31.8)$ & 0.001 \\
surface of the tongue & $3(1.1)$ & $3(1.9)$ & $0(0.0)$ & 0.414 \\
Dorsum of the tongue & $10(3.7)$ & $13(8.3)$ & $12(12.8)$ & 0.008 \\
Buccal mucosa & $34(12.5)$ & $34(21.3)$ & $30(34.1)$ & $<0.001$ \\
Floor of the mouth & $22(8.1)$ & $42(26.3)$ & $37(42.1)$ & $<0.001$ \\
Gingiva/alveolar ridge & $10(3.68)$ & $16(10.0)$ & $16(18.1)$ & $<0.001$ \\
Palate & $11(4.0)$ & $17(10.6)$ & $13(14.8)$ & 0.002 \\
Tonsils & & & & 0.214 \\
Referred evolution time & & & & \\
Up to 6 months & $102(49.8)$ & $72(35.1)$ & $31(15.1)$ & \\
6-12 months & $51(64.6)$ & $19(24.1)$ & $9(11.4)$ & \\
Over 12 months & $53(59.6)$ & $25(28.1)$ & $11(12.4)$ & \\
\hline
\end{tabular}

produce a synergistic effect (10). Lower LSCC frequency was followed by lateral border/ventral surface of the tongue, gingiva/alveolar ridge and floor of the mouth. Considering the intraoral sites, the lateral border of the tongue has been pointed to as the most common OSCC site among European and United States populations $(2,18)$. This study grouped lateral border and ventral surface of the tongue because many times both sites are concurrently affected. Mostly confirming the literature data, the tongue OSCCs in this study were more painful, frequently presenting lymph node involvement, and at least a T2 tumor or more $(16,20)$. Similar positive and statistically significant associations were observed also for gingiva/alveolar ridge and floor of the mouth.

On the opposite, lesions located in lower lip demonstrated the smallest size at the time of the diagnosis, the least amount of pain and seldom lymph node involvement. One point that should be emphasized is that the lesions in the lip are promptly detected by self-examination compared with the intraoral lesions, which explains their minor size and by consequence have the lowest symptomatology and lowest incidence of cervical metastasis, which also allows for early diagnosis and better prognosis $(9,10,16,18,20)$. The study results confirmed the reduced aggressiveness of LSCC, compared with intraoral cancer (20).

Cancer pain is also a public-health concern, as it creates a poor quality of life and limits normal function $(22,23)$. The present study showed an association between pain and intraoral OSCC lesions and between pain and the size of the lesions. Ulcer was the most frequent OSSC clinical presentation. These findings agree with other authors (22-25) who demonstrated that pain in oral cancer may be associated with advanced, endophytic invasive tumors, delivering a poor prognosis for the patients. Although this symptom is very useful in evaluating cancer progression, it has some subjectivity in its evaluation.

The OSCC cases were distributed in two periods (1959-1996 and 1997-2012). The reason for categorizing the data into these periods of time was the beginning of oral cancer campaigns in November 1996. In the last two decades the CDOD has performed campaigns to raise awareness among citizens about the importance of oral selfexamination and to promote the prevention and early detection of oral cancer. The majority of OSCC cases in this center were diagnosed after 1996 (76.9\%), reflecting the impact of the campaigns. Nevertheless, the small number of samples in the first period of time limits the comparison between the two times. Moreover, the total number of 
biopsies after November 1996 was 12,058, with OSCC cases corresponding to $5.2 \%$. This percentage is duplicated if compared with the same diagnosis done before November 1996 (2.3\% from 8148).

Most of the epidemiological studies in oral cancer analyze hospital-based or oral-health-services-based cancer registries, which naturally gather biased information, since only part of the population has access to these centers, especially in developing countries (3). The present study has the same limitation, since it is a service-based study. However, it is important to highlight that the data show the OSCC frequency during the whole existence of the CDOD, which lasts more than 50 years. This study presents some other limitations such as lack of complete information on biopsy records. Missing data were not considered in the analysis of associations and could affect some of the findings. Lack of information in retrospective studies is common $(8,9)$. Therefore, it is necessary to reinforce the importance of the correct filling by the surgeon of biopsy

Table 4. Lymph node involvement and associations

\begin{tabular}{|c|c|c|c|}
\hline Variable/Category & Yes, n (\%) & No, n (\%) & $\mathrm{p}$ value \\
\hline \multicolumn{4}{|l|}{ Site } \\
\hline Lower lip vermilion & $16(26.2)$ & 45 (73.8) & $<0.001$ \\
\hline Upper lip vermilion & $2(66.7)$ & $1(33.3)$ & 0,773 \\
\hline Labial mucosa & $1(100.0)$ & $0(0.0)$ & 0,399 \\
\hline $\begin{array}{l}\text { Lateral border/ventral } \\
\text { surface of the tongue }\end{array}$ & 59 (71.9) & $23(28.1)$ & 0,003 \\
\hline Dorsum of the tongue & $3(60.0)$ & $2(40.0)$ & 0,945 \\
\hline Buccal mucosa & 9 (52.9) & $8(47.1)$ & 0,647 \\
\hline Floor of the mouth & $46(73.0)$ & $17(27.0)$ & 0,007 \\
\hline Gingiva/alveolar ridge & $45(70.3)$ & $19(29.7)$ & 0,028 \\
\hline Palate & $16(69.6)$ & $7(30.4)$ & 0,259 \\
\hline Tonsils & $28(80.0)$ & $7(20.0)$ & 0,006 \\
\hline Size & & & $<0.001$ \\
\hline Up to $2 \mathrm{~cm}$ & $33(38.4)$ & $53(61.6)$ & \\
\hline From 2.1 to $4 \mathrm{~cm}$ & $41(63.1)$ & 24 (36.9) & \\
\hline Over $4 \mathrm{~cm}$ & $37(77.1)$ & $11(22.9)$ & \\
\hline Referred evolution time & & & 0.084 \\
\hline Up to 6 months & $76(65.5)$ & $40(34.5)$ & \\
\hline From 6 to 12 months & $22(57.9)$ & $16(42.1)$ & \\
\hline Over 12 months & $14(43.8)$ & $18(56.3)$ & \\
\hline Number of sites & & & 0,001 \\
\hline Single site & $97(51.9)$ & $90(48.1)$ & \\
\hline Multiple sites & $55(75.3)$ & $18(24.7)$ & \\
\hline
\end{tabular}

records sent with the specimens, avoiding the loss of data and minimizing this problem.

In conclusion, the study presents a demographic and clinical description of OSCC in a specific population in southern Brazil. Most of the results confirm the data from literature about sex, age, tumor location and occupation. Moreover, there was a significant correlation between LSCC and outdoor occupation and between LSCC and white skin color, highlighting the main socio-demographic and cultural characteristics of the studied population, who are mainly white, with European ascendency, and who work in agriculture. These lesions showed the smallest size, the lowest symptomatology, and the lowest incidence of cervical metastasis, because they are usually detected early. OSCC intraoral lesions were more common in sites such as tongue, gingiva/alveolar ridge and floor of the mouth, being more painful, frequently presenting lymph node involvement and at least a T2 size or more.

Table 5. Pain and associations

\begin{tabular}{|c|c|c|c|}
\hline Variable/category & Yes, n (\%) & No, n (\%) & $\mathrm{p}$ value \\
\hline \multicolumn{4}{|l|}{ Site } \\
\hline Lower lip vermilion & $4(34.4)$ & $78(65.6)$ & $<0.001$ \\
\hline Upper lip vermilion & $3(75.0)$ & $1(25.0)$ & 0,706 \\
\hline Labial mucosa & $3(37.5)$ & $5(62.5)$ & 0,086 \\
\hline $\begin{array}{l}\text { Lateral border/ventral } \\
\text { surface of the tongue }\end{array}$ & $103(83.7)$ & $20(16.3)$ & $<0.001$ \\
\hline Dorsum of the tongue & $4(80.0)$ & $1(20.0)$ & 0,51 \\
\hline Buccal mucosa & $25(71.4)$ & $10(28.6)$ & 0,507 \\
\hline Floor of the mouth & $70(80.5)$ & $17(19.5)$ & 0,002 \\
\hline Gingiva/alveolar ridge & $79(76.0)$ & $25(24.0)$ & 0,015 \\
\hline Palate & 31 (88.6) & $4(11.4)$ & 0,003 \\
\hline Tonsils & $34(89.5)$ & $4(10.5)$ & 0,001 \\
\hline Size & & & $<0.001$ \\
\hline Up to $2 \mathrm{~cm}$ & $84(53.5)$ & $73(46.5)$ & \\
\hline $2.1-4 \mathrm{~cm}$ & $80(76.2)$ & $25(23.8)$ & \\
\hline Over $4 \mathrm{~cm}$ & 37 (78.7) & $10(21.3)$ & \\
\hline Referred evolution time & & & 0,037 \\
\hline Up to 6 months & $145(71.1)$ & $59(28.9)$ & \\
\hline From 6 to 12 months & $40(57.1)$ & $30(42.9)$ & \\
\hline Over 12 months & $47(58.8)$ & $33(41.2)$ & \\
\hline Number of sites & & & $<0.001$ \\
\hline Single site & $197(60.4)$ & 129 (39.6) & \\
\hline Multiple sites & $83(86.5)$ & $13(13.5)$ & \\
\hline
\end{tabular}




\section{Resumo}

0 objetivo desse estudo foi avaliar o perfil clínico-demográfico dos casos de carcinoma de células escamosas oral (CCEO) oral registrados em um centro de diagnóstico bucal no Sul do Brasil. Oitocentos e seis indivíduos com CCEO de 1959 a 2012 foram incluidos no estudo. As variáveis coletadas foram: sexo, idade, ocupação de acordo com o ambiente de trabalho, consumo de álcool e tabaco, cor de pele, localização do tumor, tipo histológico, aparência clínica, tamanho, tempo de evolução, presença de dor e metástase linfonodal. Foi realizada análise descritiva e as associações entre as variáveis foram avaliadas usando qui-quadrado e teste exato de Fisher, com nivel de confiança de 5\%. CCE oral foi mais comum em homens $(76,6 \%)$, entre 51 e 70 anos de idade $(53,9 \%)$. Os sitios mais frequentes foram vermelhão de lábio inferior $(23,3 \%)$, língua $(20,2 \%)$ e gengiva/rebordo alveolar $(18,1 \%)$. Houve uma forte associação entre ocupação em ambiente externo e cor de pele branca com CCEO em lábio. Lesões intraorais de CCEO foram comumente mais dolorosas, maiores que $2 \mathrm{~cm}$ e apresentaram metástase linfática. Em conclusão, a maioria dos resultados confirma os dados da literatura em relação a sexo, idade, localização do tumor e ocupação. Além disso, as correlações positivas entre CCE em lábio e ocupação, entre CCEO em lábio e cor de pele branca, e entre lesões maiores e presença de dor/metástase cervical também corroboram os dados da literatura.

\section{Acknowledgements}

This study was supported by the Postgraduate Research Group of the Universidade Federal de Pelotas,. There was also a scholarship provided by CAPES (Coordenação de Aperfeiçoamento de Pessoal do Nivel Superior). The authors declare that there are no conflicts of interest.

\section{References}

1. Gillison ML. Current topics in the epidemiology of oral cavity and oropharyngeal cancers. Head Neck 2007;29:779-792.

2. Warnakulasuriya S. Global epidemiology of oral and oropharyngeal cancer. Oral Oncol 2009;45:309-316.

3. Johnson NW, Jayasekara P, Amarasinghe AA. Squamous cell carcinoma and precursor lesions of the oral cavity: epidemiology and aetiology. Periodontol 2000 2011;57:19-37.

4. Szymanska K, Hung RJ, Wunsch-Filho V, Eluf-Neto J, Curado MP, Koifman $\mathrm{S}$, et al.. Alcohol and tobacco, and the risk of cancers of the upper aerodigestive tract in Latin America: a case-control study. Cancer Causes Control 2011;22:1037-1046.

5. Hocking JS, Stein A, Conway EL, Regan D, Grulich A, Law M, et al.. Head and neck cancer in Australia between 1982 and 2005 show increasing incidence of potentially HPV-associated oropharyngeal cancers. Br J Cancer 2011;104:886-891.

6. Patel SC, Carpenter WR, Tyree S, Couch ME, Weissler M, Hackman T, et al.. Increasing incidence of oral tongue squamous cell carcinoma in young white women, age 18 to 44 years. J Clin Oncol 2011;29:14881494.

7. Bradshaw PT, Siega-Riz AM, Campbell M, Weissler MC, Funkhouser WK, Olshan AF. Associations between dietary patterns and head and neck cancer: the Carolina head and neck cancer epidemiology study. Am J Epidemiol 2012;175:1225-33.

8. Pires FR, Ramos AB, Oliveira JB, Tavares AS, Luz PS, Santos TC. Oral squamous cell carcinoma: clinicopathological features from 346 cases from a single oral pathology service during an 8-year period. J Appl
Oral Sci 2013;21:460-467.

9. Marocchio LS, Lima J, Sperandio FF, Correa L, de Sousa SO. Oral squamous cell carcinoma: an analysis of 1,564 cases showing advances in early detection. J Oral Sci 2010;52:267-273.

10. Souza RL, Fonseca-Fonseca T, Oliveira-Santos CC, Correa GT, Santos $\mathrm{FB}$, Cardoso CM, et al.. Lip squamous cell carcinoma in a Brazilian population: epidemiological study and clinicopathological associations. Med Oral Patol Oral Cir Bucal 2011;16:e757-762.

11. Antunes JL, Toporcov TN, Wunsch-Filho V. The effectiveness of the oral cancer prevention and early diagnosis program in Sao Paulo, Brazil. Rev Panam Salud Publica 2007;21:30-36.

12. Eadie D, MacKintosh AM, MacAskill S, Brown A. Development and evaluation of an early detection intervention for mouth cancer using a mass media approach. Br J Cancer 2009;101:S73-79.

13. Torres-Pereira $C$. Oral cancer public policies: is there any evidence of impact? Braz Oral Res 2010;24:37-42.

14. Mehta FS, Gupta PC, Daftary DK, Pindborg JJ, Choksi SK. An epidemiologic study of oral cancer and precancerous conditions among 101,761 villagers in Maharashtra, India. Int J Cancer 1972;10:134-141.

15. Correa MB, Tarquinio SB, Oliveira $\sqcup$, Peres MA, Peres KG, Gigante DP, et al.. Factors associated with prevalence of oral lesions and oral selfexamination in young adults from a birth cohort in Southern Brazil. Cad Saúde Pública 2013;29:155-164.

16. Zini A, Czerninski R, Sgan-Cohen HD. Oral cancer over four decades: epidemiology, trends, histology, and survival by anatomical sites. J Oral Pathol Med 2010;39:299-305.

17. Karim-Kos HE, de Vries E, Soerjomataram I, Lemmens V, Siesling $S$ Coebergh JW. Recent trends of cancer in Europe: a combined approach of incidence, survival and mortality for 17 cancer sites since the 1990s. Eur J Cancer 2008:44:1345-1389.

18. Weijers $M$, Leemans $C R$, Aartman IH, Karagozoglu KH, van der Waal I. Oral cancer trends in a single head-and-neck cancer center in the Netherlands; decline in T-stage at the time of admission. Med Oral Patol Oral Cir Bucal 2011;16:e914-918.

19. Shiboski $\mathrm{CH}$, Schmidt $\mathrm{BL}$, Jordan RC. Racial disparity in stage at diagnosis and survival among adults with oral cancer in the US. Community Dent Oral Epidemiol 2007;35:233-240.

20. Batista AC, Costa NL, Oton-Leite AF, Mendonca EF, Alencar R de C, Silva TA. Distinctive clinical and microscopic features of squamous cell carcinoma of oral cavity and lip. Oral Surg Oral Med Oral Pathol Oral Radiol Endod 2010;109:e74-79.

21. Ruback MJ, Galbiatti AL, Arantes LM, Marucci GH, Russo A, Ruiz-Cintra MT, et al.. Clinical and epidemiological characteristics of patients in the head and neck surgery department of a university hospital. Sao Paulo Med J 2012;130:307-313.

22. Viet CT, Schmidt BL. Biologic mechanisms of oral cancer pain and implications for clinical therapy. J Dent Res 2012;91:447-453.

23. Sato J, Yamazaki Y, Satoh A, Notani K, Kitagawa Y. Pain is associated with an endophytic cancer growth pattern in patients with oral squamous cell carcinoma before treatment. Odontology 2010;98:6064.

24. Sato J, Yamazaki Y, Satoh A, Onodera-Kyan M, Abe T, Satoh T, et al.. Pain may predict poor prognosis in patients with oral squamous cell carcinoma. Oral Surg Oral Med Oral Pathol Oral Radiol Endod 2011;111:587-592.

25. Dios PD, Leston JS. Oral cancer pain. Oral Oncol 2010;46:448-451. 